\title{
The state of women's rugby union in South Africa: Recommendations for long-term participant development
}

\author{
M Posthumus \\ UCT/MRC Research Unit for Exercise Science and Sports Medicine, Department of Human Biology, Sport Science Institute of South Africa, \\ University of Cape Town, Cape Town, South Africa \\ M Posthumus, $\mathrm{PhD}$
}

Corresponding author: $M$ Posthumus (mposthumus@me.com)

\begin{abstract}
Several international rugby unions, including the South African Rugby Union, have adopted the long-term athlete development (LTAD) model, which is based on physiological principles that categorise players into specific stages of development. The original model proposes different age categories for boys and girls within each specific stage of development. This review: (i) discusses the current state of junior female rugby in South Africa; (ii) discusses the evidence for gender-specific differences in the LTAD model; and (iii) recommends a future strategy for LTAD within female rugby in South Africa, considering the current approaches of other international unions.
\end{abstract}

S Afr J SM 2013;25(1):28-35. DOI:10.7196/SAJSM.461

The most common model used to develop and nurture talent across all sporting codes is the long-term athlete or participant development (LTAD or LTPD) model. Prior to the implementation of structured talent-development plans, too much emphasis was placed on competition and results among paediatric and adolescent athletes. ${ }^{[1,2]}$ The LTAD model is based on physiological principles which allow players to be categorised into specific stages of development. ${ }^{[3]}$ The classic stages of development for late specialisation sports, such as rugby, include the 'fundamental', 'learning to train', 'training to train', 'training to compete' and 'training to win' phases. ${ }^{[3]}$ Several international rugby unions, including the South African Rugby Union (SARU), have adopted the same terminology for these phases. SARU has outlined potential stages of development for boys according to age: 'fundamental' - age 6 - 9 years (U7 - U9); 'learning to train' - age 10 - 13 years (U10 - U13); 'train to train' - age 14 - 16 years (U14 U16); 'training to compete' - 17 - 18 years (U17 - U19); and 'training to win' - age $\geq 19$ years. These categorisations have been used as a point of departure and, based on available literature, are explored further here in terms of whether or not they are indeed scientifically supported, justifiable and feasible for both men's and women's rugby.

The LTAD model was originally developed based on the concept of 'windows of trainability' ${ }^{[3]}$ - specific periods in a young athlete's life when he/she is uniquely sensitive to specific modes of training and is capable of enhanced adaptation. ${ }^{[3]}$ As biological maturity varies greatly among young athletes, it is suggested that a practical solution would be to use a non-invasive measure of biological maturity. Consequently, peak height velocity (PHV) is used as the critical reference point for the design of optimal individual development programmes. Whether windows of trainability actually exist has been debated in the scientific literature. Here, the relevant evidence pertaining to girls is reviewed in greater detail.
As outlined above, SARU has suggested age-group recommendations for the various stages of their LTPD plan. Although the stages of development are well described for men's rugby, women's rugby remains less structured and defined within South Africa (SA) and in several other international rugby unions. Consequently, the objective of this article is to provide a best-practice framework for structuring women's rugby in SA. Here, relevant peer-reviewed scientific literature is reviewed to establish best-practice guidelines for the development of LTAD within women's rugby; more specifically, the evidence for a similar or altered LTPD structure for women's rugby in SA is reviewed.

\section{Review of current structures in SA}

There is currently no uniform structure for girl's rugby within SA. To document the structures currently in place within each provincial union, the female rugby co-ordinators from each union were contacted telephonically and interviewed (Table 1). Although girls and women play rugby within all SA provincial unions, the extent of participation varies greatly. Certain provincial rugby unions have several clubs and schools which play structured league matches on a weekly basis across most age categories, while other unions have no female participants, or merely have a small group of girls and women who practise together to prepare for, as an example, the U16 interprovincial week (Table 1).

Within SA there is currently no standardised format for introducing young girls to rugby and developing their fundamental rugby skills. Certain provincial unions do introduce the game of rugby to young girls (U6 - U11) through Tag rugby, Mini-rugby or touch rugby; however, this is not standard and a number of unions offer no structure for their introductory participation. The majority of introductory rugby structures for girls involve mixed-gender participation with boys. Furthermore, although certain unions do 
Table 1. A brief description of all junior (U6 - U18) women's rugby activities in the SA rugby provincial unions ${ }^{\star}$

\begin{tabular}{ll}
\hline Province & Activities \\
\hline Blue Bulls Limpopo & $\begin{array}{l}\text { Young girls from the ages of } 6 \text { - } 8 \text { years play Mini-rugby with the boys. At U13 level there is a festival where U13 } \\
\text { girls play 15-a-side rugby. For high school girls, there is only an U18 league. The U16 provincial team is selected } \\
\text { from these league matches. }\end{array}$
\end{tabular}

Blue Bulls Tshwane Young girls from the ages of 6 - 8 years play Mini-rugby with the boys. At U10 level there is a Tag school league. There is an interschool/club league for U14, U16 and U18 girls. They play 15-a-side rugby.

Boland Girls are only introduced at U16 level. They play an interschool competition in preparation for the national interprovincial tournament. U18 girls play 7-a-side rugby.

Border Girls are introduced to the game only at U13 level. There is a large club and school structure for U13 and U16 15 -a-side rugby. The U13 and U16 teams play in regional festivals. U18 girls join and play within the senior club structures.

Eastern Province Young girls are introduced to the game at U9 level. They play touch rugby and there are festivals arranged for competition at this level. There are both U12 and U16 structured leagues. At U12 level, girls play 7-a-side rugby. At U16 level, girls play 15-a-side rugby.

Falcons There are currently no structures for junior women's rugby in this region. There is insufficient participation to put together an U16 provincial team. Even at senior level there is no structured club competition, merely a group of players who practise together.

Free State $\quad$ Young girls are introduced through Tag rugby at U6 - U8 level. There are no structures at intermediate levels. There is no school or club structure within the province. There are training groups organised by the province to prepare an U16 provincial team for the U16 provincial tournament. There is an U18 structure for playing 7-a-side.

Golden Lions Young girls are introduced to the game playing Tag rugby. There are structured competitions where girls and boys play Tag rugby together at U11 and U13 level. For high school girls, there are U16 and U18 competition structures. Regular festivals are arranged where the 6 youth clubs within the union play against each other.

Griffons

Young girls are introduced to the game at U9 and U11 level through Mini-rugby. Young boys and girls play separately. There is an interschool/club competition for U16 and U18 girls. There is no structured plan for girls between the age groups of U12 and U16.

Griquas

Girls are currently only introduced to the game at U18 level. U16 girls participate in the U18 age category. Although there are no structured competitions, there are clubs that have groups of girls who participate in camps, trials and occasional festivals. There have also been 7-a-side festivals previously, arranged specifically for U16 girls.

KwaZulu-Natal The U9, U11, U13, U14 and U15 age groups play Tag and touch rugby. U9 girls are introduced to the game and play with the boys. These junior age groups play against other schools. Only at U16 level do the girls play competitive 15-a-side rugby. They play interschool/club rugby and a provincial team is represented at the national U16 week. There is also an U18 competition between schools and clubs.

Leopards Girls play informally from the U11 age group onwards. They play with boys, where they participate in noncontact practises, but do not play any matches or partake in competitions. Girls only start playing at U16. They play 15 -a-side rugby in preparation for the national inter-provincial tournament. There is no school or club competition system.

Mpumalanga Girls are introduced into rugby structures at U16 level. There are 7 youth clubs in the province, which play rugby at U16 and U18 level. They play regular development tournaments against each other in 7-a-side format. The provincial 15 -a-side team is selected from the 7 -a-side tournaments.

South Western Girls are introduced into rugby structures at U16 level. There are a few clubs and schools that play rugby, but there Districts is no structured competition. There are both U16 and U18 teams within the schools and clubs. 'Friendlies' are arranged between the different teams as a form of competition.

Western Province Young girls are introduced into the game through playing Mini-rugby at U9 level. There is a school league that accommodates U13s, U16s and U18s. U13s and U18s play 7-a-side. The U16 girls play 15-a-side rugby in preparation for the inter-provincial U16 tournament.

*All descriptions were collected from telephonic interviews with the respective provincial union co-ordinators of female rugby (particulars available from the author).

introduce the game of rugby to young girls, participation is mostly lost up until the U16 age group.

Most SA provincial unions have a structured plan for the participation of girls in the U16 age group, predominantly due to a SARU-administered U16 inter-provincial girls rugby tournament.
The extent to which U16 girls' rugby is structured is mostly reliant on the number of girls playing rugby in each specific union. A union such as Border has a large number of school and club teams (approximately 80 teams), which play against each other at regular rugby festivals, whereas other unions do not have any clubs or schools which play 
women's rugby. The unions without any clubs or schools that play women's rugby select their provincial team from a relatively small group of girls who practise as a team to represent their union in the inter-provincial U16 tournament.

Currently, after girls across all SA provincial unions are introduced to rugby at U16 level, there is no standardised plan for continued participation. Although there are club and school leagues within certain provinces that continue playing at U18 level, certain unions adopt the 7-a-side format at U18 level and others have absolutely no competition structure at U18 level. In the latter, girls either stop playing rugby or play within the senior women's structures. At the senior level, there are women's rugby club structures within most provincial unions. The extent of participation across all junior levels is summarised in Table 2. All descriptions were collected from telephonic interviews with each respective provincial union's coordinator for female rugby (particulars available from the author).

Table 2. A summary of the extent of junior (U6 - U18) women's rugby in SA rugby provincial unions

\begin{tabular}{|c|c|c|c|c|}
\hline Province/union & $\begin{array}{l}\text { Are girls introduced to } \\
\text { the game at U6 - U10 } \\
\text { level? }\end{array}$ & $\begin{array}{l}\text { Is there any structure } \\
\text { for participation from } \\
\text { U11 to U15? }\end{array}$ & $\begin{array}{l}\text { Is there any structure } \\
\text { for participation at } \\
\text { U16 level? }\end{array}$ & $\begin{array}{l}\text { Is there any structure } \\
\text { for participation at U18 } \\
\text { level? }\end{array}$ \\
\hline Blue Bulls Limpopo & $\begin{array}{l}\text { Yes (U6 - U8 play Mini- } \\
\text { rugby) }\end{array}$ & $\begin{array}{l}\text { Yes (U13 15-a-side } \\
\text { competition) }\end{array}$ & $\begin{array}{l}\text { No (U16 girls play in } \\
\text { the U18 structure) }\end{array}$ & $\begin{array}{l}\text { Yes (interschool/club } \\
\text { league for U18) }\end{array}$ \\
\hline Blue Bulls Tshwane & $\begin{array}{l}\text { Yes (U6 - U8 play Mini- } \\
\text { rugby; U10 play Tag } \\
\text { rugby) }\end{array}$ & $\begin{array}{l}\text { Yes (U14 interschool/ } \\
\text { club league) }\end{array}$ & $\begin{array}{l}\text { Yes (U16 interschool/ } \\
\text { club league) }\end{array}$ & $\begin{array}{l}\text { Yes (interschool/club } \\
\text { league for U18) }\end{array}$ \\
\hline Boland & No & No & $\begin{array}{l}\text { Yes (U16 interschool/ } \\
\text { club league) }\end{array}$ & $\begin{array}{l}\text { Yes (7-a-side league for } \\
\text { U18) }\end{array}$ \\
\hline Border & No & $\begin{array}{l}\text { Yes (U13 school/club } \\
\text { league) }\end{array}$ & $\begin{array}{l}\text { Yes (U16 school/club } \\
\text { league) }\end{array}$ & $\begin{array}{l}\text { No (U18 girls participate } \\
\text { in senior rugby) }\end{array}$ \\
\hline Eastern Province & $\begin{array}{l}\text { Yes (U9 girls play touch } \\
\text { rugby) }\end{array}$ & $\begin{array}{l}\text { Yes (U12 girls play } \\
7 \text {-a-side in a structured } \\
\text { league) }\end{array}$ & $\begin{array}{l}\text { Yes (U16 school/club } \\
\text { league) }\end{array}$ & No \\
\hline Falcons & No & No & No & No \\
\hline Free State & $\begin{array}{l}\text { Yes (U6 and U8 play } \\
\text { Tag rugby) }\end{array}$ & No & $\begin{array}{l}\text { Yes (there are training } \\
\text { groups organised to } \\
\text { select a provincial team; } \\
\text { no competitions) }\end{array}$ & $\begin{array}{l}\text { Yes (7-a-side league for } \\
\text { U18) }\end{array}$ \\
\hline \multirow[t]{2}{*}{ Golden Lions } & \multirow[t]{2}{*}{ No } & \multirow{2}{*}{$\begin{array}{l}\text { Yes (Tag competition } \\
\text { for U11 and U13; boys } \\
\text { and girls mixed) }\end{array}$} & Yes & Yes \\
\hline & & & $\begin{array}{l}\text { U16 interschool/club } \\
\text { league }\end{array}$ & $\begin{array}{l}\text { U18 interschool/club } \\
\text { league }\end{array}$ \\
\hline Griffons & $\begin{array}{l}\text { Yes (U9 and U11 play } \\
\text { Mini-rugby) }\end{array}$ & No & $\begin{array}{l}\text { Yes (U16 interschool/ } \\
\text { club league) }\end{array}$ & $\begin{array}{l}\text { Yes (U18 interschool/club } \\
\text { league) }\end{array}$ \\
\hline Griquas & No & No & $\begin{array}{l}\text { No (U16 girls play in } \\
\text { the U18 structure) }\end{array}$ & $\begin{array}{l}\text { Yes (groups of girls who } \\
\text { practise together and play } \\
\text { 7-a-side) }\end{array}$ \\
\hline KwaZulu-Natal & $\begin{array}{l}\text { Yes (U9 and U11 play } \\
\text { Tag and touch rugby) }\end{array}$ & $\begin{array}{l}\text { Yes (U13 and U14 play } \\
\text { Tag and touch rugby) }\end{array}$ & $\begin{array}{l}\text { Yes (U16 interschool/ } \\
\text { club league) }\end{array}$ & $\begin{array}{l}\text { Yes (U18 interschool/club } \\
\text { league) }\end{array}$ \\
\hline Leopards & No & $\begin{array}{l}\text { No (girls play } \\
\text { informally with boys, } \\
\text { but no girl structure) }\end{array}$ & $\begin{array}{l}\text { Yes (U16 girls play } \\
15 \text {-a-side rugby in } \\
\text { preparation for the } \\
\text { provincial tournament) }\end{array}$ & No \\
\hline Mpumalanga & No & No & $\begin{array}{l}\text { Yes (U16 7-a-side } \\
\text { tournaments) }\end{array}$ & $\begin{array}{l}\text { Yes (U18 7-a-side } \\
\text { tournaments) }\end{array}$ \\
\hline $\begin{array}{l}\text { South Western } \\
\text { Districts }\end{array}$ & No & No & $\begin{array}{l}\text { Yes (U16 school/club } \\
\text { teams) }\end{array}$ & $\begin{array}{l}\text { Yes (U18 school/club } \\
\text { teams) }\end{array}$ \\
\hline Western Province & $\begin{array}{l}\text { Yes (there is U9 Mini- } \\
\text { rugby) }\end{array}$ & $\begin{array}{l}\text { Yes (there is an U13 } \\
\text { 7-a-side school league) }\end{array}$ & $\begin{array}{l}\text { Yes (there is an U16 } \\
\text { interschool/club league) }\end{array}$ & $\begin{array}{l}\text { Yes (there is an U18 } \\
\text { 7-a-side school league) }\end{array}$ \\
\hline
\end{tabular}




\section{Summary}

- There is no consistent participation structure in women's rugby in SA at a junior level (U6 - U18).

- Currently, in the majority of provincial unions, participation structures revolve around the U16 inter-provincial tournament organised by SARU.

- Less than half of the provincial unions ( $47 \%$ or $7 / 15 ; 1$ province was sub-divided) introduce rugby to young girls.

- Only $20 \%(3 / 15)$ of the provincial unions claim to have girls participating across all the junior age categories.

- The lack of progressive age-group structures results in girls playing above their specific age group.

- There are no LTAD plans for women's rugby in any of the provinces.

\section{Gender-specific differences in the LTAD model}

As mentioned above, the LTAD or LTPD model was originally developed based on the concept of 'windows of trainability ${ }^{\text {'[3] }}$ - specific periods in a young athlete's life when he/she is uniquely sensitive to specific modes of training and capable of enhanced adaptation. The stages of the LTPD model theoretically align with these periods of putative enhanced adaptation (Fig. 1). As the objective is to formulate evidence for a similar or altered LTPD structure for women's rugby, when compared with men's rugby, the rationale for age categories in the original Balyi and Hamilton ${ }^{[3]}$ model is reviewed here and appraised.

\section{The fundamental stage}

The objective of the first stage of the LTPD plan is termed the 'fundamental' or physical literacy stage. ${ }^{[3]}$ The original LTPD model ${ }^{[3]}$ recommended that boys aged 6 - 9 years and girls aged 6 - 8 years participate in this developmental focus period. The objective of this stage is to learn the fundamental movement skills, with emphasis on physical literacy and the 'ABCs' - an acronym for 'athleticism, balance, co-ordination and speed. ${ }^{[3]}$ Fundamental movement and sport skills include walking, running and jumping, and catching, hopping and galloping, respectively. These activities are the basis of a wide range of physical activities and sport situations. ${ }^{[4]}$ This fundamental stage, as originally proposed, ${ }^{[3]}$ occurs approximately at a similar age to reports of peak brain maturation. Rabinowicz ${ }^{[5]}$ noted that peak brain maturation occurred between the ages of $6-8$ and $10-12$ years. Furthermore, several studies have investigated the effect of training on fundamental sport skills. ${ }^{[6,7]}$ Although these studies were not specifically performed among girls, they demonstrate that a longterm school-based intervention can improve physical literacy among 6 - 9-year-olds; however, a 6-year follow-up demonstrated that the year-long intervention failed to result in long-term improvements in physical literacy. ${ }^{[6]}$ Although the development of fundamental sports skills are undeniably important, ${ }^{[8]}$ there is a lack of scientific evidence to support the existence of a defined or critical period of enhanced adaptation. Furthermore, there is also a lack of evidence for the gender disparities in age at which such an accelerated adaptation window occurs.

The fundamental stage of development is also reported to include the first, of two, windows of accelerated adaptation to speed. ${ }^{[3]}$ This window is reported to occur at age 6 - 8 years for girls, and 7 - 9

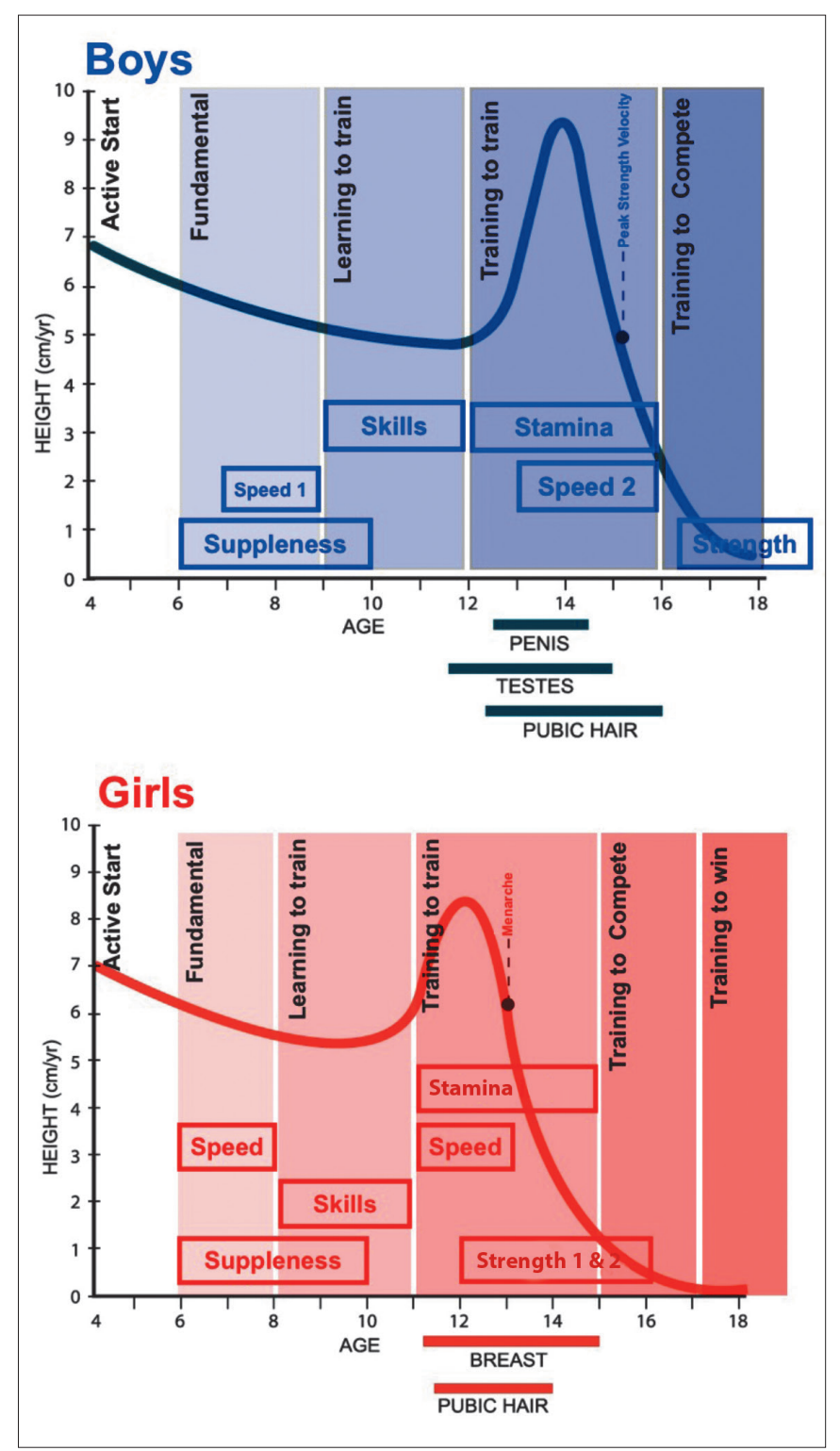

Fig. 1. The LTAD plan originally proposed by Balyi and Hamilton, ${ }^{[3]}$ including the windows of trainability that each stage is based upon for males (top) and females (bottom). Adapted from Balyi and Way. ${ }^{[1]}$

years for boys. This period was reported to align with accelerated increases in speed among boys and girls, most probably due to neuromuscular factors. ${ }^{[3]}$ It has been suggested that 2 periods of accelerated adaptation to speed occur: the first between the ages of 5 and 9 years in both males and females, and the second between the ages of 12 and 15 years in boys and at 12 years in girls. ${ }^{[9,10]}$ From the age of 12 years, the progression of maximal speed development is greatly reduced in females. ${ }^{[11]}$ The disparity in maximal speed development has been proposed to be due to body dimensions, body composition and related maturational changes. ${ }^{[11,12]}$ The first period of accelerated adaptation has been suggested to be linked to central nervous system development and improved co-ordination. ${ }^{[9-11,13]}$ However, no studies have measured training-induced adaptation to maximal speed development in children aged 5 - 9 years; therefore, there is no evidence to support the first period of enhanced adaptation 
to speed. Although an increased muscle function during adolescence theoretically supports the second period of speed adaptation, Butterfield et al. ${ }^{[12]}$ found no association between maturational factors (growth rate and body mass) and improved maximal running speed. This second period of adaptation has also been reported to be due to hormone-related fast-twitch muscle-fibre hypertrophy. However, research shows that the trainability of speed during adolescence is similar to that during pre-adolescence. ${ }^{[14]}$ Furthermore, it has been reported that the magnitude of training-related changes in speed in pre-adolescent and adolescent boys remains lower than that of changes in adults. ${ }^{[15]}$ In addition, the adaptations to speed are lost with de-training. ${ }^{[15]}$ The periods of increased adaptation surrounding the pre-adolescent and adolescent periods remain difficult to study due to the multi-factorial nature of speed development and the plethora of maturational changes during this period of development. There is, however, no strong scientific evidence to support these two windows/ periods of adaptation for speed development. Moreover, there is no evidence to support the theory that males and females should emphasise speed training at different ages.

\section{The 'learning to train' stage}

The second stage of development is termed the 'learning to train' stage. Balyi and Hamilton ${ }^{[3]}$ recommended that boys between the ages of $9-12$ years and girls aged $8-11$ years participate in this developmental focus period. The objective of this stage is to build overall sports skills. This stage is aligned with the 'window of accelerated adaptation to motor co-ordination. ${ }^{[3]}$ Although this window is aligned with a period of peak brain maturation, there is also no convincing scientific evidence for segregating males and females at this stage of development. As discussed previously, periods of peak brain development occur at $6-8$ years and $10-12$ years. ${ }^{[5]}$ Although this aligns with the window of opportunity for physical literacy ${ }^{[5]}$ and motor co-ordination, ${ }^{[16]}$ there is no evidence that this period offers greater adaptation to training.

\section{The 'training to train stage'}

The third stage of development in the LTPD model is termed the 'training to train stage'. Balyi and Hamilton ${ }^{[3]}$ recommended that boys aged 12 - 16 years and girls aged $11-15$ years participate in this developmental focus period. The objective of this stage is to build an aerobic base, build strength towards the end of the phase and further develop sport-specific skills. This stage is aligned with the 'window of accelerated adaptation to aerobic and strength training' and includes the onset of peak height velocity $(\mathrm{PHV})^{[3]}$ - the point in adolescence at which the rate of vertical growth is the greatest.

Studies have shown that peak development of oxygen uptake occurs in the periods after PHV and puberty. ${ }^{[17,18]}$ A review of longitudinal studies concluded that the peak development of aerobic capacity occurs between the ages of 12 and 16 years in boys and girls. ${ }^{[19]}$ Certain cross-sectional studies, however, have reported that the peak aerobic development occurs between the ages of 10 and 16 years for boys and 7 and 13 years for girls. The age at which optimal aerobic development occurs therefore remains inconclusive. ${ }^{[19]}$ Furthermore, considering the evidence, a window of trainability for aerobic capacity also remains inconclusive. Weber et al. ${ }^{[20]}$ suggested that decreased sensitivity to aerobic capacity occurs during the middle of PHV and that there is an increased sensitivity either side of the middle of PHV. Alternatively, Rowland ${ }^{[21]}$ found a $10 \%$ and a $9 \%$ increase in peak oxygen uptake in the period before PHV in boys and girls, respectively. There are, therefore, clear discrepancies in the literature surrounding the evidence for the actual window of trainability for aerobic performance. ${ }^{[18]}$ Although studies have suggested that PHV is a determinant of this window, there is no clear evidence of how this window is different in boys and girls. Further longitudinal studies with precise assessment of training stimuli are required to further investigate this window. ${ }^{[7]}$

Balyi and Hamilton ${ }^{[3]}$ reported 2 windows of accelerated adaptation for strength training in females: the first at the onset of PHV, and the second at the onset of menarche. However, there are no reported studies on strength-training responses in adolescents where PHV was considered or measured with adequate controls. ${ }^{[7]}$ Only 1 of 3 studies which measured adaptations to strength training found an association between magnitude of adaptation and maturational level. ${ }^{[19,22,23]}$ Vrijens ${ }^{[19]}$ found greater improvements in arm and leg strength in post-pubertal (mean age 16.8 years) adolescents compared with prepubescent adolescents (mean age 10.5 years). There were no significant differences in the magnitude of strength adaptation between the two maturational groups in the other 2 studies. ${ }^{[22,23]}$ The evidence for the existence of a strength-training window of opportunity is therefore limited and no longitudinal studies have investigated the magnitude of strength adaptation within various stages of development in females. Therefore, there is no scientific rationale for separating boys and girls at the 'training to train' stage.

\section{The 'training to compete' stage}

The fourth stage in the LTPD model is termed the 'training to compete' stage. Balyi and Hamilton ${ }^{[3]}$ recommended that boys aged 16 - 18 years and girls aged 15 - 17 years participate in this developmental focus period. The objective of this stage is to optimise fitness preparations, performance and sport-, individual- and position-specific skills. ${ }^{[3]}$ It is reported that this stage includes the second 'window of accelerated adaptation to strength' for males and females. ${ }^{[3]}$ However, as described above, further research is required.

\section{The 'training to win' stage}

The fifth stage of development in the LTPD model is termed the 'training-to-win' stage. Balyi and Hamilton ${ }^{[3]}$ recommended that men aged $\geq 18$ years and women aged $\geq 17$ years participate in this developmental focus period. The objective of this stage is to maximise fitness preparations, performance and sport-, individual- and position-specific skills. This is the final phase of athletic preparation.

\section{Summary}

- The LTPD model has aligned itself to emphasise training capacities during specific 'windows of opportunity'

- However, scientific data to support the concept of windows of opportunity are lacking

- There is a lack of scientific evidence to support the concept of different windows of opportunity and therefore different age separation of the LTPD stages for girls v. boys

- A uniform LTPD model should be used for both boys and girls. 
How other international unions have adapted the LTAD model for females

Due to the available resources and performances of their respective national teams, this discussion includes the development plans adopted by Australia, Canada, England, Ireland and New Zealand (online resources listed in Appendix I). The plan adopted specifically for girls' rugby development is discussed here.

Among the 5 international unions described, only Canada, England and Ireland have blatantly structured their development programme according to Balyi and Hamilton's LTAD model. ${ }^{[3]}$ However, each international union has adopted a structured model that divides participation into specific age categories. Since Balyi, ${ }^{[1,3]}$ who first described the LTAD model, advises Canadian and UK sport, their respective models follow the original Balyi-described model either directly or with only slight modification. Both England and Canada have allocated different ages for boys and girls within each of the developmental stages. The Canadian LTAD model follows the original LTAD model exactly as described by Balyi and Hamilton ${ }^{[3]}$ (Fig. 1). The England model has been adapted slightly for girls from the original model by combining the 'learning to train' and 'training to train' stages. Besides this, girls still enter the following stages 1 year sooner than boys. Although the Ireland model incorporates the LTAD developmental stages, both girls and boys enter the respective developmental stages at the same age.

The LTAD model seems less influential in the Australian and New Zealand developmental models and strategic plans. There are no female-specific plans and details available for Australia and New Zealand, and it can therefore be assumed that the females' developmental plan and structure is no different to that of the males. The New Zealand Black Ferns Strategic Plan, a high-performance plan for women, is currently in the process of being developed and will be implemented in 2013. No details are currently available.

It is agreed (Australia, Canada and England) that girls in the U12 age group and younger may participate in mixed-gender modified competitions and matches. Within the England model, U12 girls may apply for dispensation to play down in the U11 age category of the England Rugby Football Union (RFU) continuum. In addition, clubs with enough girls participating may field U12 girls' teams against each other. These U12 girls' matches are played under the laws of U10 Mini-rugby outlined in the RFU continuum. After the U12 age band, England, Australia and Ireland introduce game and law variations for girls' rugby. In England, U15 girls aged 12 - 15 years play a modified 13-player version of the game. In Australia, participation is low and schools are encouraged to arrange competition for girls aged 13 - 18 years to play a non-contact, modified version of the game, called Walla rugby. In Australia, talented girls may play senior rugby. In Ireland, only slight law variations differentiate the boys' and girls' games within all junior age bands. In Canada, boys and girls play the same format of the game within each stage of the LTAD model. The similarities and differences between the international unions are summarised in Fig. 2.

\section{Summary}

- The structure adopted by each international rugby union is unique

- It is common that U12 girls and younger may participate in mixed-gender rugby

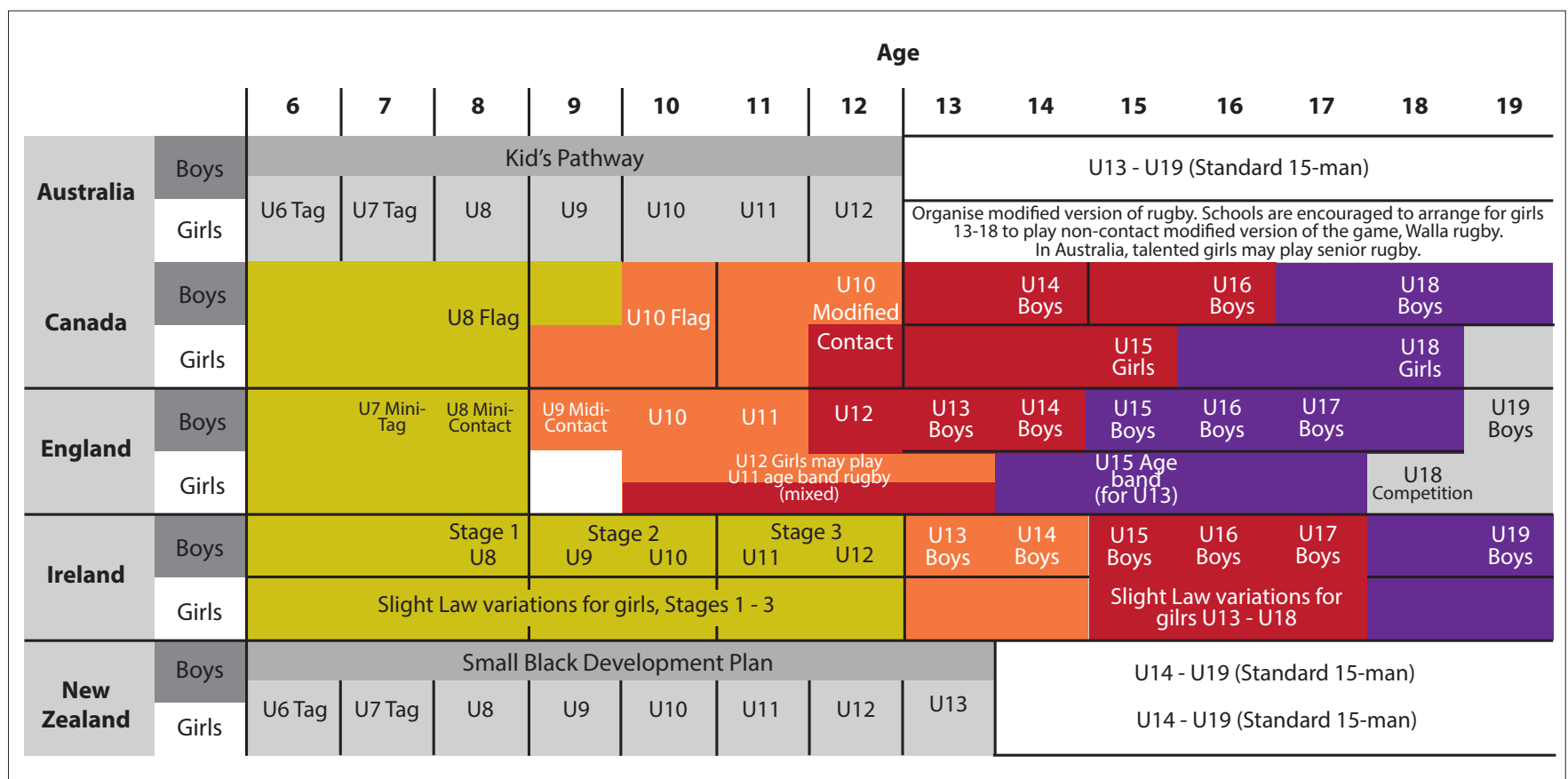

Fig. 2. Female v. male development structures for 5 selected leading international rugby unions. Incorporated LTAD model stages: 'fundamental' (yellow), 'learning to train' (orange), 'training to train' (red), and 'training to compete' (purple). The New Zealand and Australian development models (grey) do not align with the Balyi LTAD model. The age groups at which competition occurs are indicated. A solid black line separating boys and girls indicates separate participation (no line indicates mixed-gender participation). Refer to Appendix I for online resources used to formulate this table. 
- Thereafter (U12 - U19), a combination of standard 15-player rugby, Sevens and modified/other non-contact formats (e.g. Walla rugby) are adopted by the respective unions.

\section{Practical guidelines}

Women's rugby in SA is not yet well structured. The primary objective of SARU should be to establish participation or competitive structures across all the age groups from U6 to senior rugby. Although the original Balyi and Hamilton ${ }^{[3]}$ model proposes that males and females have separate LTAD models, this review highlights that there is no scientific evidence supporting this proposed structure. SARU is developing a detailed LTPD approach for male participation. There is no scientifically supported reason for a separate female LTPD model. The SARU LTPD model should be applied to both males and females.

\section{Conclusion}

There is no consistent participation in women's rugby in SA across all the provincial unions. Currently, in the majority of the provincial unions, participation structures revolve around the U16 interprovincial tournament organised by SARU. Less than half of the provincial unions (7/15; one union was subdivided; $47 \%$ ) introduce rugby to young girls and only $20 \%$ (3/15; one union was subdivided) of the provincial unions have girls participating across all the junior age categories. There are currently no LTPD plans within any of the provincial unions.

The original LTPD model separates males and females by chronological age and thus recommends gender-specific models. This original LTAD model was based on physiological periods of theoretical enhanced adaptation (or windows of opportunity) of physical capacities. Research has, however, shown that: (i) scientific data to support the presence of these periods (or windows) are lacking; and (ii) there is a dearth of scientific evidence to support the concept of different age separation of the LTPD stages for girls compared with boys. The practical implication is that there is no reason for a separate female LTPD model. The SARU LTPD approach should be applied to both males and females.

Acknowledgements. This article was commissioned by the BokSmart National Rugby Safety Programme, implemented on behalf of SARU and the Chris Burger/Petro Jackson Players' Fund. The goal of the programme is to: teach safe and effective techniques; reduce the incidence and severity of injury; make the game safer for all involved; and improve rugby performance. This article also forms part of the evidence-based research in SARU's LTPD initiative driven by the Game Development division. The author thanks Dr Wayne Viljoen, Justin Durandt and Professor Mike Lambert for their input.

\section{References}

1. Balyi I, Way R. Long-Term Planning For Athlete Development: The Training to Train Phase. Canada: BC Coach, 1995:2-10.

2. Bompa T. From Childhood to Champion Athlete. West Sedona, AZ, USA: Veritas Publishing, 1995.

3. Balyi I, Hamilton A. Long-Term Athlete Development: Trainability in Children and Adolescents. Windows of Opportunity. Optimal Trainability. Victoria, BC: National Coaching Institute British Columbia \& Advanced Training and Performance Ltd, 2004.

4. Higgs C, Balyi I, Way R, Cardinal C, Norris S, Bluechardt M. Developing Physical Literacy: A Guide for Parents of Children Aged 0 to 12. Vancouver, BC: Canadian Sports Centres, 2008.

5. Rabinowicz T. The differentiated maturation of the cerebral cortex. In Falkner F, Tanner J, Eds. Human Growth: A Comprehensive Treatise, Vol. 2. Postnatal Growth: Neurobiology. 2nd ed. New York: Plenum, 1986:385-410.

6. Barnett LM, van Beurden E, Morgan PJ, Brooks LO, Avigdor Zask, A, Beard JR. Six year follow-up of students who participated in a school-based physical activity intervention: A longitudinal cohort study. Int J Behav Nutr Phys Act 2009;6:48. [http:// dx.doi.org/10.1186/1479-5868-6-48]

7. Ford P, De Ste Croix M, Lloyd R, et al. The Long-Term Athlete Development model: Physiological evidence and application. J Sports Sciences 2011;29(4)389-402. [http:// dx.doi.org/10.1186/1479-5868-6-48]

8. Gallahue D, Donnelly F. Development of Physical Education for All Children. 4th ed. Champaign, IL: Human Kinetics, 2003.

9. Borms, J. The child and exercise: An overview. J Sports Sci 1986;4:3-20.

10. Viru A, Loko J, Harro M, Volver A, Laaneots L, Viru M. Critical periods in the development of performance capacity during childhood and adolescence. Eur J Phys Educ 1999;4:75-119. [http://dx.doi.org/10.1080/17408990040106]

11. Whithall J. Development of locomotor co-ordination and control in children. In: Savelsberg GJP, Davids K, Van der Kamp J, eds. Development of Movement Coordination in Children: Applications in the Field of Ergonomics, Health Sciences and Sport. London: Routledge, 2003:251-270.

12. Butterfield SA, Lehnhard R, Lee J, Coladarci T. Growth rates in running speed and vertical jumping by boys and girls ages 11-13. Percept Mot Skills 2004;99:225-234.

13. Malina RM, Bouchard C, Bar-Or O. Growth, maturation and Physical Activity. Champaign, IL: Human Kinetics, 2004.

14. Venturelli M, Bishop D, Pettene L. Sprint training in preadolescent soccer players. Int J Sports Physiol Perform 2008;3:558-562.

15. Fournier M, Ricci J, Taylor A, Ferguson R, Montpetit R, Chaltman B. Skeletal muscle adaptation in adolescent boys: Sprint and endurance training and detraining. Med Sci Sports Exerc 1982;14:453-456.

16. Cratty BJ. Perceptual motor development in infants and children. 3rd ed. Englewood Cliffs, NJ: Prentice-Hall, 1986.

17. Katch VL. Physical conditioning of children. J Adolesc Health Care 1983;3:241-246 [http://dx.doi.org/10.1010/50197-0070]

18. Rowland TW. The "trigger hypothesis" for aerobic trainability: A 14-year follow-up (editorial). Pediatr Exerc Sci 1997;9:1-9

19. Vrijens J. Muscle development in the pre and post pubescent age. Medicine in Sport 1978;11:152-158.

20. Weber G, Kartodihardjo W, Klissouras, V. Growth and physical training with reference to heredity. Journal of Applied Physiology 1976;40;211-215.

21. Rowland TW. Aerobic response to endurance training in prepubescent children: A critical analysis. Med Sci Sports Exerc 1985;17:493-497.

22. Lillegard WA, Brown EW, Wilson DJ, Henderson R, Lewis, E. Efficacy of strength training in prepubescent males and females: Effects of gender and maturity. Paediatr Rehab 1997;1:147-157.

23. Pfeiffer R, Francis R. Effects of strength training on muscle development in prepubescent, pubescent and postpubescent males. Phys Sportsmed 1986;14:134143. 
Appendix I

Online resources used to collate the data on the structure of the international rugby unions

\begin{tabular}{|c|c|}
\hline Country & Resources (accessed 17 July 2012) \\
\hline Australia & $\begin{array}{l}\text { Australian Rugby Union } \\
\text { - http://www.rugby.com.au/tryrugby/KidsRugby/KidsPathway/2012KidsPathwayModifications.aspx } \\
\text { - http://www.rugby.com.au/tryrugby/PathwaytoGold/Background.aspx } \\
\text { - http://www.rugby.com.au/tryrugby/KidsRugby/KidsPathway.aspx } \\
\text { - http://www.rugby.com.au/tryrugby/Playing/U13U19.aspx } \\
\text { - http://www.rugby.com.au/tryrugby/Playing/Womens.aspx } \\
\text { - http://www.rugby.com.au/LinkClick.aspx?fileticket=f4pEC-L2izU\%3D\&tabid=1595 } \\
\text { - http://www.rugby.com.au/LinkClick.aspx?fileticket=YbizKwsempQ\%3d\&tabid=1595 }\end{array}$ \\
\hline Canada & $\begin{array}{l}\text { Rugby Canada } \\
\text { • http://www.rugbyalberta.com/clientuploads/Coaching/RC_LTRD11.pdf }\end{array}$ \\
\hline England & $\begin{array}{l}\text { England Rugby Football Union } \\
\text { - http://www.rfu.com/TakingPart/Coach/CoachResourceArchive/TechnicalJournalArchive/ /media/Files/2009/ } \\
\text { Coaching/Articles/TechnicalJournal/2005/1stQuarter/LTAD20booklet.ashx } \\
\text { - http://www.rfu.com/ /media/Files/2010/WomensRugby/RFUW\%20Player\%20Pathway\%201011.ashx } \\
\text { - http://www.sussexrugby.co.uk/dyn/_assets/_pdfs/rfu-documnets-for-clubs/RFUW_Law_Guidance_Card.pdf } \\
\text { - http://www.rfu.com/ /media/Files/2011/WomensRugby/U13_Girls_Regulations_2011_2012.ashx } \\
\text { - http://www.rfu.com/managingrugby/managingschoolsrugby/secondaryschools/teachingandlearning/ } \\
\text { pelessonplans/tagtotackl }\end{array}$ \\
\hline Ireland & $\begin{array}{l}\text { Ireland Rugby Union } \\
\text { - http://origin.irishrugby.ie/development/long-term_player_development.php } \\
\text { - http://www.irishrugby.ie/downloads/Game_Variations_Womens_Rugby.pdf } \\
\text { - http://www.irishrugby.ie/downloads/Age_Grade_Regulation_Variations_2011_to_2012.pdf }\end{array}$ \\
\hline New Zealand & $\begin{array}{l}\text { New Zealand Rugby Union (including Small Blacks) } \\
\text { • http://files.allblacks.com/comms/Strategies/NZRU_Womens_Strategy_2012.pdf http://www.grammarjuniors.org. } \\
\text { nz/resources/SmallBlackRugbyRules.pdf }\end{array}$ \\
\hline
\end{tabular}

